\title{
SISTEM PERTANIAN TERPADU HEDGEROW MENINGKATKAN PENDAPATAN PETANI LAHAN KERING
}

\author{
Integrated Farming Systems Hedgerow Increase Farmers' Income on Dry Land \\ "Darmawan Risal \\ *Fakultas Pertanian dan Kehutanan, Universitas Indonesia Timur \\ (corresponding email : darmawanrisalrauf@yahoo.com)
}

\begin{abstract}
Agricultural systems carried out by local farmers on dry land sloping topography Gowa in particular proved a negative impact on production which impact on decreasing the income of farmers. This study aims to determine whether the Hedgerow integrated farming systems may increase the income of dryland farmers. The research was conducted on dry land with a slope of $30 \%$ in Gowa. Research using randomized complete block design with four treatments and two replications. Components of each treatment that is $\mathrm{P} 0$ (corn, mangosteen, Gliricidia), P1 (corn, mangosteen, Gamal, mischantus), P2 (corn, mangosteen, Gamal, Setaria), P3 (corn, mangosteen, Gamal, elephant grass) economic analysis using nalisis production, $\mathrm{R} / \mathrm{c}$ Ratio and NPV. The results of the analysis of production per season showed P3 treatment is treated with the highest income of USD 19,123,446 and in line with the highest total receipts per year. $\mathrm{R} / \mathrm{c}$ ratio integrated farming systems Hedgerow very feasible where P3 has feasibility level high while the NPV P0 is treated with NPV room where the first year until the 6th year that are in deficit figures while P1, P2, P3 obtained an increase from the first year until the 20th year. This study proves that integrated farming systems Hedgerow increase farmers' income and very worthy to be applied on dry land marginal bertopografi particularly skewed.
\end{abstract}

Keywords: $\begin{aligned} & \text { Hedgerows, productive, } \\ & \text { integrated }\end{aligned}$

\section{PENDAHULUAN}

Lahan kering di Kabupaten Gowa merupakan salah satu media tanam bagi petani untuk melakukan aktivitas pertanian. Potensi luasan yang tinggi menjadikan lahan kering dapat dimanfaatkan sebagai lahan produktiv yang nantinya dapat meningkatkan pendapatan pertanian di wilayah ini. Hampir $70 \%$ luasan wilayah ini terdiri dari lahan kering yang kesemuanya itu berada pada topografi $>15 \%$. Berdasarkan luasan tersebut, lahan kering memiliki potensi besar untuk menunjang pembangunan pertanian di Indonesia. Namun demikian, optimalisasi pemanfaatan lahan kering masih dihadapkan pada berbagai tantangan, diantaranya dalam hal penerapan sistem pertanian yang tidak sesuai, penanggulangan erosi yang tidak tepat dan tingkat kesuburan lahan yang sangat rendah.

Penurunan produktivitas pertanian khususnya tanaman pangan pada lahan kering sangat mempengaruhi pendapatan petani. Faktor utama yang menjadi kendala adalah penerapan sistem monokultur secara terus-menerus oleh petani. Sistem monokultur selain berpengaruh langsung terhadap erosi dan produksi, biaya yang dikeluarkan oleh petani dalam sistem pemupukan dan pengelolaannya juga sangat tinggi. Akibatnya, pendapatan yang diperoleh lebih rendah dibandingkan 
dengan biaya yang harus dikeluarkan oleh petani. Penelitian (Lai, 2001) menjelaskan bahwa korelasi antara produksi dan hilangnya lapisan atas tanah akibat erosi di Ohio sangat parah yang awalnya hanya sebesar $17 \%$ meningkat menjadi $21 \%$. Penelitian lain melaporkan bahwa produksi pertanian menurun sekitar $2,7 \%$ untuk setiap kehilangan $1 \mathrm{~cm}$ lapisan atas tanah. Selain itu, rata-rata penurunan produksi pertanian sekitar $0,2 \%$ tahun $^{-1}$ atau penurunan $3,1 \% \mathrm{~cm}^{-1}$ dari pengikisan bagian atas pada tanah Ultisol (Den Biggelaar et al., 2001). Erosi juga dapat menyebabkan perubahan penggunaan lahan akibat lahan yang kurang produktif lagi. Estimasi kerugian produksi dan dampak ekonomi dari erosi untuk produksi jagung, gandum, kedelai, dan kapas menggunakan ekstrapolasi berbasis tanah dari erosi sejak tahun 1939 sangatlah besar di Amerika Serikat. Nilai estimasi kerugian produksi dari empat jenis pertanian yang disebabkan oleh erosi adalah sekitar $\$ 56.000 .000$ pada tahun 2000 (Den Biggelaar et al., 2001).

Berbagai upaya dapat dilakukan untuk meningkatkan pendapatan petani di lahan kering Kabupaten Gowa, salah satu diantaranya adalah penerapan sistem pertanian terpadu. Sistem pertanian terpadu adalah sistem penggunaan lahan dengan memadukan banyak jenis usaha tani yang saling berinteraksi satu dengan yang lainnya pada satu tempat yang sama (Macdicken dan Vergara, 1990). Penerapan sistem pertanian terpadu oleh (Kabaluapa, 2004) di bagian timur Alabama, menemukan bahwa model pertanian terpadu pada berbagai kemiringan dapat menanggulangi erosi yang terjadi. Sistem pertanian terpadu merupakan pencampuran dari berbagai sub-sistem yang juga telah terbukti praktis dan ekonomis dalam memperbaiki kualitas tanah di lereng yang curam dibandingkan dengan sistem konservasi mekanik. Dalam sebuah studi ditemukan bahwa pertanian terpadu dengan jarak $4 \mathrm{~m}$, dengan melibatkan leucaena dengan jagung dapat memberikan keuntungan ekonomis bagi petani. Manfaat dari pertanian terpadu adalah karena efek konservasi tanahnya yang rendah dan dapat mempertahankan hasil yang konstan sepanjang waktu.

Teknologi integrasi tanaman dengan sistem hedgerow (barisan tanaman pagar menjadi salah satu solusi dalam upaya peningkatan produktivitas dan sejalan dengan peningkatan pendapatan ekonomi lahan kering yang berbasis lingkungan dan berkelanjutan. Penggunaan hedgerows dalam sistem pertanaman seperti mischantus (Miscanthus), rumput gajah (Pennisetum purpureum), setaria (Setaria sphacelata), gamal (Gliricidia sepium) manggis (Garcinia Mangostana L) sebagai tanaman pohon dan jagung (Zea mays) sebagai tanaman utama diyakini dapat memberikan manfaat ekologi dan produksi yang tinggi. Berdasarkan uraian di atas, maka perlu dilakukan penelitian sistem pertanian terpadu hedgerow meningkatkan pendapatan petani lahan kering. Penelitian ini dilaksanakan untuk meningkatkan pendapatan petani di lahan kering.

\section{METODE PENELITIAN}

Penelitian ini dilaksanakan pada lahan kering dengan kemiringan $30 \%$ yang terletak di Kabupaten Gowa, Sulawesi Selatan.

Alat yang digunakan dalam penelitian ini adalah; GPS (Geografi Position System), alat pertanian, alat penggali, alat pembuka lahan, alat potong, alat ukur, penakar curah hujan, gelas ukur, alat menulis, dan alat laboratorium. Bahan yang digunakan adalah Tanaman hedgerows, tanaman buah dan tanaman utama (gamal, setaria, mischantus, rumput gajah, manggis dan jagung pulut), ember kapasitas $30 \mathrm{~L}$, talang karet, pipa 1,5 dan 3 inci, pengikat, gelas ukur, waring, bambu dan bahan-bahan analisis laboratorium. 
Sistem pertanaman menggunakan rancangan acak kelompok dengan empat perlakuan dan dua ulangan. Komponen setiap perlakuan terdiri dari P0 (sistem pertanian terpadu hedgerows; jagung, manggis dan gamal), P1 (sistem pertanian terpadu hedgerows; jagung, manggis, gamal dan mischantus) P2 (sistem pertanian terpadu hedgerows; jagung, manggis, gamal dan setaria) P3 (sistem pertanian terpadu hedgerows; jagung, manggis, gamal dan rumput gajah). Analisis produksi menggunakan analysis of varians. Analisis pendapatan ekonomi selama dua puluh tahun (asumsi produktivitas tanaman manggis) dengan menghitung R/c Ratio dan NPV.

\section{HASIL DAN PEMBAHASAN}

\section{Hasil}

Hasil analisis pengaruh perlakuan terhadap produksi tanaman (Tabel 1) menunjukkan P3 merupakan perlakuan terbaik dan berbeda nyata terhadap perlakuan lainnya. Produksi jagung pipilan kering (Tabel 2) menunjukkan perlakuan $\mathrm{P} 3$ berbeda nyata dengan P0, P1, P2. Pertumbuhan tanaman manggis dengan parameter tinggi tanaman dan jumlah daun juga menunjukkan bahwa P3 berbeda nyata dengan P1, P2, P3. Produksi P3 diperoleh dari korelasi sifat fisik kimia tanah terhadap produksi manggis yang berbeda nyata dengan perlakuan lainnya. Analisis produksi jagung, biomassa pangkasan menunjukkan bahwa perlakuan P3 adalah perlakuan terbaik. Dari hasil produksi tersebut di atas menunjukkan bahwa P1, P2 dan P3 membutuhkan investasi yang sama sedangkan P0 investasi yang dibutuhkan lebih rendah. Hasil analisis produksi per musim menunjukkan perlakuan P3 merupakan perlakuan dengan pendapatan tertinggi yaitu Rp 19.123.446 dan sejalan dengan total penerimaan tertinggi pertahun
(Tabel 3). $\mathrm{R} / \mathrm{c}$ ratio sistem pertanian terpadu hedgerow sangat layak untuk dilaksanakan dimana P3 memiliki tingkat kelayakan tertinggi sedangkan NPV P0 merupakan perlakuan dengan nilai NPV terendah dimana tahun pertama sampai tahun ke-6 berada pada angka defisit sedangkan P1, P2, P3 memperoleh peningkatan mulai tahun pertama sampai tahun ke-20 (Tabel 4).

Tabel 1. Pengaruh perlakuan terhadap produksi

\begin{tabular}{|c|c|c|c|c|c|}
\hline \multirow{2}{*}{ Uraian } & \multirow{2}{*}{ Satuan } & \multicolumn{4}{|c|}{ Perlakuan } \\
\hline & & P0 & P1 & $\mathbf{P 2}$ & P3 \\
\hline $\begin{array}{l}\text { Produksi Jagung } \\
\text { Pipilan Kering }\end{array}$ & $\mathrm{kg} \mathrm{ha}^{-1}$ & $1462^{\mathrm{c}}$ & $3641^{a b}$ & $3585^{a b}$ & $5172^{a}$ \\
\hline $\begin{array}{c}\text { Tinggi Tanaman } \\
\text { Manggis }\end{array}$ & $\mathrm{cm}$ & $42,27^{\mathrm{a}}$ & $40,18^{a}$ & $42,55^{\mathrm{a}}$ & $37,92^{a}$ \\
\hline $\begin{array}{c}\text { Jumlah Daun } \\
\text { Tanaman } \\
\text { Manggis }\end{array}$ & Lembar & $12,62^{\mathrm{c}}$ & $15,62^{b}$ & $16,37^{b}$ & $17,25^{\mathrm{a}}$ \\
\hline $\begin{array}{c}\text { Biomassa } \\
\text { Pangkasan } \\
\text { (Gamal dan } \\
\text { Rumput) }\end{array}$ & $\mathrm{kg} \mathrm{ha}^{-1}$ & $1267^{c}$ & $2623^{c}$ & $7822^{b}$ & $\underset{\mathrm{a}}{11233}$ \\
\hline
\end{tabular}

Ket; Uji lanjut Duncon $\mathrm{p}=<0,05$. Huruf kecil pada baris yang sama merupakan representasi beda nyata dan tidak beda nyata.

Tabel 2. Data berat biji sampel jagung pipilan kering pada setiap perlakuan

\begin{tabular}{ccccc}
\hline \multirow{2}{*}{$\begin{array}{c}\text { Uraian Sampel } \\
\text { Jagung Pipilan }\end{array}$ Kering } & \multicolumn{5}{c}{ Rata-rata berat biji tongkol-1 } \\
\cline { 2 - 5 } & P0 & \multicolumn{4}{c}{ P1 } & P2 & P3 \\
\cline { 2 - 5 } & 33.250 & 80.580 & 91.630 & 119.454 \\
1 & 35.247 & 91.719 & 93.318 & 122.722 \\
2 & 41.660 & 74.194 & 86.268 & 152.859 \\
3 & 37.697 & 89.569 & 80.497 & 116.231 \\
4 & 34.848 & 94.468 & 104.564 & 129.123 \\
5 & $\mathbf{1 8 2 . 7 0 1}$ & $\mathbf{4 3 0 . 5 2 9}$ & $\mathbf{4 5 6 . 2 7 7}$ & $\mathbf{6 4 0 . 3 8 8}$ \\
Jumlah & $\mathbf{3 6 . 5 4 0}$ & $\mathbf{8 6 . 1 0 6}$ & $\mathbf{9 1 . 2 5 5}$ & $\mathbf{1 2 8 . 0 7 8}$ \\
\hline Rata2 & & & &
\end{tabular}


Tabel 3. Total pendapatan pada setiap perlakuan per musim

\begin{tabular}{cccccc}
\hline \multirow{2}{*}{ Perlakuan } & \multirow{2}{*}{ Satuan } & P0 & P1 & P2 & P3 \\
\cline { 3 - 6 } & & \multicolumn{2}{c}{ (Rp) } \\
\hline Jagung Tua & $\mathrm{kg} \mathrm{ha}^{-1}$ & 4.384 .830 & 10.923 .270 & 10.755 .540 & 15.516 .780 \\
Brangkasan Jagung Tua & $\mathrm{kg} \mathrm{ha}^{-1}$ & 453.334 & 1.120 .000 & 1.013 .334 & 1.360 .000 \\
Pangkasan Gamal & $\mathrm{kg} \mathrm{ha}^{-1}$ & 253.332 & 213.332 & 320.000 & 380.000 \\
Pangkasan Rumput & $\mathrm{kg} \mathrm{ha}^{-1}$ & - & 311.110 & 1.244 .444 & 1.866 .666 \\
Manggis & - & - & - & - & - \\
Total Pendapatan & & $\mathbf{5 . 0 9 1 . 4 9 6}^{\mathbf{c}}$ & $\mathbf{1 2 . 5 6 7 . 7 1 2}^{\text {ab }}$ & $\mathbf{1 3 . 3 3 3 . 3 1 8}^{\text {ab }}$ & $\mathbf{1 9 . 1 2 3 . 4 4 6}^{\mathbf{a}}$ \\
\hline
\end{tabular}

Ket; Huruf kecil pada baris yang sama merupakan representasi dari berbeda nyata dan tidak berbeda nyata.

Tabel 4. Perhitungan rata-rata $\mathrm{R} / \mathrm{c}$ ratio dan NPV penerapan sistem pertanian terpadu dalam waktu 20 tahun

\begin{tabular}{ccccc}
\hline Rata-rata & \multicolumn{4}{c}{ Perlakuan } \\
\cline { 2 - 5 } (Produksi/Tahun) & P0 & P1 & P2 & P3 \\
\hline Investasi & 2.400 .000 & 2.566 .667 & 2.566 .667 & 2.566 .667 \\
Cost & 48.183 .500 & 46.401 .000 & 46.401 .000 & 48.253 .500 \\
Reveneu & 225.287 .155 & 247.731 .261 & 250.028 .079 & 267.118 .469 \\
Benefit & 177.103 .655 & 201.330 .261 & 203.627 .079 & 218.864 .969 \\
R/c ratio & 4 & 5 & 5 & 5 \\
NPV & 19.338 .023 & 23.239 .389 & 23.583 .912 & 25.591 .720 \\
\hline
\end{tabular}

Sumber; Data primer setelah diolah, 2014.

\section{Pembahasan}

Peningkatan produksi pada P3 dipengaruhi oleh rendahnya erosi yang terjadi, rendahnya hara yang hilang bersama aliran permukaan dan sedimen. Suplai unsur hara N yang tinggi dan konstan pada perlakuan P3 menjadikan pertumbuhan jumlah daun semakin meningkat sejalan dengan pertumbuhan tinggi tanaman manggis. Persaingan kebutuhan hara NPK pada jaringan tanaman tidak terjadi karena suplai hara dari tanah sangat cukup untuk tanaman manggis. Selain itu, input biomassa pangkasan yang berfungsi sebagai pupuk hijau dari rumput dan gamal dengan kandungan hara makro dalam jumlah yang cukup menjadikan produksi P3 berbeda dengan perlakuan lainnya. Rumput gajah pada P3 merupakan tanaman yang dapat memperbaiki kondisi tanah yang rusak akibat erosi. Tanaman ini juga dapat hidup pada tanah kritis dimana tanaman lain relatif tidak dapat tumbuh dengan baik. (Okaraonye dan Ikewuchi, 2009) menjelaskan bahwa biomassa rumput gajah pada daerah tropis dapat mencapai 80 ton $\mathrm{ha}^{-1}$ dengan kandungan selulosa 30,91\%. (Gonggo et al., 2005) menambahkan bahwa tanaman rumput gajah membuat tanah lebih gembur. Kondisi tersebut dapat meningkatkan porositas, yang menyebabkan terjadinya aerasi yang lebih baik.

Perlakuan P0 tidak membutuhkan biaya tanaman rumput sehingga investasi 
yang dibutuhkan lebih rendah. Memasuki masa produksi pembuahan tanaman manggis pada tahun ke-7, biaya investasi yang dibutuhkan pada setiap perlakuan sama yaitu Rp. 28.000.000. Peningkatan pendapatan yang diperoleh P3 dipengaruhi oleh penambahan penerimaan dari sub sistem produksi jagung, biomassa tanaman yang lebih tinggi dibandingkan dengan perlakuan lainnya. Penerimaan yang diperoleh pada P2 dan P3 tidak berbeda nyata. Hal ini dipengaruhi oleh hasil produksi jagung yang diperoleh dari setiap sub-sistem hampir sama. Sedangkan P0 merupakan perlakuan dengan penerimaan yang lebih rendah dibandingkan dengan perlakuan lainnya. Produksi yang lebih rendah dari jagung dan biomassa menjadikan penerimaan P0 sangat rendah. Perlakuan P0 merupakan perlakuan dengan produksi permusim terendah dibandingkan dengan lainnya. Interaksi dari beberapa sub sistem yang berbeda menghasilkan produksi yang berbeda dan keuntungan yang berbeda baik pada kemampuan menahan erosi, kualitas tanah melalui daur ulang hara serta pendapatan ekonomi. Perlakuan P3 merupakan perlakuan dengan tingkat pendapatan yang tinggi dibandingkan dengan perlakuan lainnya. Perlakuan P3 sangat baik dalam mengatasi masalah erosi dan kehilangan hara. Daur ulang hara yang dapat dimanfaatkan baik oleh tanaman, terbukti bahwa hara yang hilang bersama aliran permukaan dan erosi sangat sedikit. Selain itu, input pupuk hijau yang berasal dari biomassa pangkasan rumput dan gamal berbanding lurus dengan pertumbuhan dan produksi jagung.

Perlakuan P2 dan P1 memperoleh pendapatan produksi total pertahun yang tidak berbeda nyata. Jumlah biomassa yang ada pada P2 lebih tinggi dibandingkan dengan P1 sedangkan pada produksi jagung $\mathrm{P} 1$ lebih tinggi dibandingkan $\mathrm{P} 2$. Hal ini dipengaruhi karena mischantus merupakan tanaman rumput yang tidak terlalu membutuhkan air dalam jumlah yang banyak sehingga adaptasi tanaman mischantus tehadap curah hujan yang tinggi pada masa awal tanaman menjadikan biomassanya berkurang. Mischantus memiliki kelebihan daur hara yang berbeda dibandingkan dengan setaria. (Haines, 2011) menjelaskan bahwa mischantus merupakan rumput $\mathrm{C} 4$ yang sangat sesuai terhadap lahan tidak produktiv dan tahan terhadap kekeringan. P2 berupa rumput setaria memiliki jumlah biomassa yang cukup tinggi. Daya adapatasi tanaman setaria pada kondisi apapun menjadikan setaria dapat tumbuh pada kondisi apapun. Selain itu, jumlah anakan setaria mampu bertambah hingga 18 anakan setelah pemangkasan. Selain jumlah anakan yang banyak, akar tanaman setaria yang membentuk tikar dan berlimpah menjadikan biomassanya tinggi.

Perlakuan P0 memperoleh produksi pendapatan yang terendah dan berbeda nyata dengan perlakuan lainnya. Efektivitas biomassa rumput menjadi faktor utama pada setiap perlakuan. Tidak adanya rumput dan kurangnya biomassa penahan erosi menjadikan hara lebih banyak terbuang bersama dengan aliran permukaan. Selain itu, biomassa yang menjadi sumber hara dalam bentuk pupuk hijau juga banyak terbuang. akibatnya tanaman jagung defisit hara sehingga tidak memberikan hasil yang optimal. P3 memiliki nilai kelayakan tertinggi dibandingkan dengan perlakuan lainnya. Hal ini dipengaruhi oleh perbandingan total penerimaan dengan biaya operasional yang tinggi dibandingkan dengan perlakuan lainnya. P2 tidak berbeda nyata dengan P1 mulai pada tahun pertama hingga tahun ke-20. Perlakuan P0 merupakan R/c ratio terendah dibandingkan dengan perlakuan lainnya. Hal ini dipengaruhi oleh perbandingan penerimaan yang diperoleh lebih rendah dibandingkan dengan jumlah biaya yang dikeluarkan. 
Sistem budidaya P3 merupakan yang terbaik dengan nilai NPV tertinggi dibandingkan dengan perlakuan lainnya. Perlakuan P2 dan P1 memiliki nilai NPV yang tidak berbeda nyata namun berbeda nyata terhadap P0 dan P3. Perlakuan P0 merupakan perlakuan dengan nilai NPV terendah. Perlakuan P0 pada tahun pertama sampai tahun ke-6 berada pada angka defisit (Gambar 5) dan mengalami keuntungan pada tahun ke-tujuh sedangkan P1, P2 dan P3 memperoleh peningkatan mulai tahun pertama sampai tahun-20. Jumlah NPV pada P0 mengalami peningkatan pada tahun ke 8 dimana produksi buah pada tahun tersebut mulai meningkat mencapai 600 hingga 1000 buah per pohon. Hasil analisis juga menunjukkan bahwa nilai NPV pada setiap perlakuan memiliki perbedaan karena perbandingan jumlah pendapatan yang diperoleh berbeda dengan total biaya yang dikeluarkan.

P3 merupakan perlakuan terbaik karena dapat menurunkan aliran permukaan dan sedimen, mengurangi kekurangan dan kehilangan hara, meningkatkan daur ulang hara, menghasilkan biomassa yang tinggi serta memperoleh pendapatan yang lebih tinggi. Dari hasil ini membuktikan bahwa sistem pertanian terpadu berbasis hedgerow sangat layak untuk di terapkan pada lahan kering marginal khususnya yang bertopografi miring

\section{KESIMPULAN}

Berdasarkan hasil penelitian maka dapat disimpulkan bahwa sistem pertanian terpadu hedgerow mampu meningkatkan pendapatan petani lahan kering di Kabupaten Gowa.

\section{PUSTAKA}

Den Biggelaar, C., R. Lai, K. Wiebe, and V. Breneman. 2001. Impact of Soil Erosion on Crop Yields In North America, p. 1-52 Advances in Agronomy, Vol. 72.

Gonggo, B. M., Hermawan, B., and Anggraeni, D. 2005. Pengaruh jenis tanaman penutup dan pengolakan tanah terhadap sifat fisika tanah pada lahan alang - alang. Jurnal ilmu-ilmu pertanian Indonesia. 7(1):44-55.

Haines., S.A. 2011. Nitrogen and Phosphorus Fertilizer Effects on Establishment of Miscanthus xgiganteus in North Carolina. Thesis submitted to the Graduate Faculty of North Carolina State University. Soil Science Raleigh, North Carolina.

Kabaluapa. N.K. 2004. Agronomic, Economic and Environmental effects of Alley Cropping and Terracing in North Alabama. Desertase of Auburn Uneversity. Alabama.

Lai, R. 2001. Soil degradation by erosion. Land Degradation \& Development 12:519-539.

Macdicken KG, Vergara NT. 1990. Agroforestry, Clasification and Management. A Wiley-Interscience Publication. 0-471-83871-4.

Okaraonye, C. C., and Ikewuchi, J. C. 2009. Nutritional and antinutritional components of Pennisetum purpureum Schumach. Pakistan journal of Nutritional 8(1): 32-34. 